\title{
Wear and friction of composites of an epoxy with boron containing wastes
}

\author{
Tayfun Uygunoğlư ${ }^{1 *}$, Witold Brostow² and Ibrahim Gunes ${ }^{3}$ \\ ${ }^{1}$ Civil Engineering Department, Faculty of Engineering, Afyon Kocatepe University, \\ Afyonkarahisar, Turkey \\ ${ }^{2}$ Laboratory of Advanced Polymers \& Optimized Materials - LAPOM, Department of Materials Science \\ and Engineering, Center for Advanced Research and Technology - CART, \\ University of North Texas, Denton, TX, USA \\ ${ }^{3}$ Department of Metallurgical and Materials Engineering, Faculty of Technology, \\ Afyon Kocatepe University, Afyonkarahisar, Turkey \\ *uygunoglu@aku.edu.tr
}

\begin{abstract}
Polymer surface coatings provide superior adhesion to substrates, some flexibility and corrosion resistance. On the other hand, 400,000 ton of boron wastes are generated each year. We have developed polymer composites based on epoxy resins containing up to $50 \mathrm{wt}$. \% of boron wastes and determined their pin-on-disk dynamic friction, wear, Shore D hardness and surface roughness. The hardness and wear resistance increase with increasing boron waste concentration. An equation, with parameters dependent on the load, relating wear rate to hardness is provided. Dynamic friction increases with increasing surface roughness, as represented by the equation. Further, dynamic friction is an increasing function of the wear rate. Micrographs of pure epoxy without fillers shows traces after pin-on-disk testing, with tears, breaks and cracks. For the composites, we observe simpler and relatively homogeneous surfaces.
\end{abstract}

Keywords: boron-containing waste, epoxy composites, abrasive wear, dynamic friction, shore hardness, roughness.

\section{Introduction}

The largest boron deposits are found in Turkey with a worldwide share of $72 \%$ in terms of $\mathrm{B}_{2} \mathrm{O}_{3}$ content. During the obtaining of boron minerals such as tincalconite $\left(\mathrm{Na}_{2} \mathrm{O} \cdot 2 \mathrm{~B}_{2} \mathrm{O}_{3} \cdot 5 \mathrm{H}_{2} \mathrm{O}\right)$, ulexite $\left(\mathrm{Na}_{2} \mathrm{O} \cdot 2 \mathrm{CaO} \cdot 5 \mathrm{~B}_{2} \mathrm{O}_{3} \cdot 16 \mathrm{H}_{2} \mathrm{O}\right)$ and colemanite $\left(2 \mathrm{CaO} \cdot 3 \mathrm{~B}_{2} \mathrm{O}_{3} \cdot 5 \mathrm{H}_{2} \mathrm{O}\right)$, about 400,000 tons of different types of boron wastes are formed and rejected in tailing dams per year ${ }^{[1]}$. A few studies are carried out on evaluation of boron wastes. Kavas et al. ${ }^{[1]}$ investigated the production of artificial lightweight aggregates (LWA) by using four boron-containing wastes (BW), named as Sieve (SBW), Dewatering (DBW), Thickener (TBW) and Mixture (MBW) waste, from Kirka Boron plant in Turkey. They reported that SBW and DBW boron-containing wastes combined with a clay mixture and quartz sand can be used for the manufacturing of LWA. Kurama et al. ${ }^{[2]}$ used a dewatering sieve waste (TSW) of Etibor Kırka Borax company (Turkey) in order to develop an experimental terracotta floor tile body composition in combination with a feldspathic waste provided from a local sanitaryware plant and a ball clay. The results indicated a prospect for using the TSW as a raw material in mixtures with both clay and sanitaryware waste for the production of a terracotta floor tile body. The utilization of boron-containing clay wastes as cement additives was investigated by Özdemir and Öztürk ${ }^{[3]}$. It was observed that the first clay wastes may be used as cement additives up to $5 \%$ or $10 \%$.

On the other hand, polymeric materials are noted for their versatility, high resistance to chemicals, outstanding adhesion to a variety of substrates, toughness, high electrical resistance, durability at high and low temperatures, low shrinkage upon cure, flexibility, and the ease with which they can be poured or cast without forming bubbles ${ }^{[4-6]}$. Various kinds of polymers and polymer-matrix composites reinforced with metal particles have a wide range of industrial applications such as heaters, electrodes ${ }^{[7]}$, composites with thermal durability at high temperature ${ }^{[8]}$, etc. The inclusion of such particulate fillers into polymers for commercial applications is primarily aimed at the cost reduction and stiffness improvement.

The wear behavior of polymeric materials has drawn a considerable interest in recent years. Polymers and their composites are being increasingly used in a various applications where resistance to abrasive wear is important ${ }^{[9]}$. These range from its use as a material (in applications such as machinery parts and biomedical joint replacements) to its use as a glazing material where damage results in loss of optical properties. Polymers are ideal materials for bearing applications due to their general resistance to corrosion, galling and seizure, their tolerance to small misalignments and shock loading and their low coefficients of friction; as glazing materials, their low density and high toughness along with high transparency are desirable properties ${ }^{[10,11]}$. The acceptability of polymeric materials for abrasive wear conditions largely depends upon its mechanical load carrying capacity and the wear rate. The practical choice of polymeric materials is however not only determined by the mechanical and tribological properties, but also by the price, simplicity of production, processing and the practical limitations in the 
real application ${ }^{[12,13]}$. The performance of polymers sliding against hard and smooth counterfaces is determined by the transfer ability and buildup of a polymer film. Efficiency of materials in reducing friction and wear depends on the molecular polymer structure and counterface type. However, only few publications are available on the comparison of the tribological properties of composites under dry sliding and abrasive wear conditions ${ }^{[14-18]}$.

In general, studies take into account to enhance the wear resistance of polymer materials ${ }^{[19-22]}$. Epoxy resins are the most commonly used thermoset plastic in polymer matrix composites which do not give off reaction products when they cure and thus have low cure shrinkage ${ }^{[4-6]}$. They also have good adhesion to other materials, good chemical and environmental resistance, good chemical properties and good insulating properties. We have investigated the influence of boron-containing wastes as a filler on wear and friction characteristics of epoxy composites.

\section{Experimental}

\subsection{Materials and sample preparation}

The boron-containing wastes used in the study were provided by the Eti Holding Borax Plant in Kırka/Eskişehir, and were taken from the outlet of dewatering sieve of dissolution units. Its maximum particle size was $500 \mu \mathrm{m}$. Chemical component of waste is presented in Table 1.

Commercially available Teknobond 300 epoxy resin along with hardener was used as matrix material in fabrication of different specimens. Epoxy resin has modulus of $3.42 \mathrm{GPa}$, and possess density of $1100 \mathrm{~kg} / \mathrm{m}^{3}$. For processing, the mix ratio by weight was: 2 parts of the epoxy resin and 1 part of the amine based hardener. The required mixture of resin and hardener (see Table 2 below) were made by mixing them in a beaker by stirring the mixture by a rod, taking care that no air should be entrapped inside the solution. The composites were created at the room temperature.

The required ingredients of resin, hardener and boron waste were mixed thoroughly and the mixture so made was transferred to a mold cavity coated with a separator. Steel moulds in size $\varnothing=50 \mathrm{~mm}$ were used for casting of the specimens. Curing was done at room temperature for approximately $24 \mathrm{~h}$. After curing, the specimens were de-molded. Shore $\mathrm{D}$ hardness of the specimens was measured at 8 different locations at the same distance from the surface and averages calculated.

\subsection{Tests on polymer composites}

Dynamic friction and abrasive wear were determined with a tribometer in a ball-on-disc configuration. $\mathrm{WC}+\mathrm{Co}$ balls of $2.0 \mathrm{~mm}$ diameter from H.C. Starck Ceramics, $\mathrm{GmbH}$, Munich, were used. Experiments were carried out under a dry friction condition at room temperature with applied loads of 5.0, 10.0 and $15.0 \mathrm{~N}$ and with the sliding speed of $0.2 \mathrm{~m} / \mathrm{s}$ at a sliding distance of $125 \mathrm{~m}$. Before and after each wear test, each sample and abrasion element was cleaned with alcohol. After the tests, the wear volumes of the samples were quantified by multiplying cross-sectional areas of wear by the width of the wear track obtained from the device Tribotechnic Rugosimeter, namely

Wear rate $=\mathrm{W}=$ Worn volume /

(Applied load x Sliding distance), $\mathrm{mm}^{3} / \mathrm{Nm}$

Dynamic friction values as function of the sliding distance were obtained using dedicated software. Surface profiles of the wear tracks on the samples and surface roughness were measured by a Tribotechnic Rugosimeter. All the tests were performed on the three specimens and the averages calculated.

\section{Results and Discussion}

\subsection{Surface roughness}

Figure 1 shows the surface roughness values. In samples with high volume waste content, the roughness is lower than in the control pure epoxy specimens, except for $10 \%$ boron waste.

\subsection{Wear and hardness}

Wear rates of our composites are displayed in Figure 2 for the three loads applied as a function of the boron content. As seen in that Figure, wear of composites decreases when increasing the content of boron-containing waste material. The highest wear values are obtained for control series at each loading conditions. The range of wear rates varies from $17 \times 10^{-5}$ to $2 \times 10^{-5} \mathrm{~mm}^{3} / \mathrm{Nm}$ at $5.0 \mathrm{~N}$, from

Table 1. Chemical content of boron wastes.

\begin{tabular}{cccccccccc}
\hline Oxide & $\mathbf{B}_{2} \mathbf{O}_{3}$ & $\mathrm{SiO}_{2}$ & $\mathbf{A l}_{2} \mathbf{O}_{3}$ & $\mathbf{C a O}$ & $\mathbf{M g O}$ & $\mathbf{K}_{2} \mathbf{O}$ & $\mathrm{Na}_{2} \mathbf{O}$ & $\mathrm{Fe}_{2} \mathbf{O}_{3}$ & $\begin{array}{c}\text { Loss of Ignition } \\
(\mathbf{L O I})\end{array}$ \\
\hline Content, $\%$ & 12.09 & 15.5 & 1.38 & 17.7 & 13.79 & 0.5 & 3.34 & 0.22 & 34.4 \\
\hline
\end{tabular}

Table 2. Compositions and hardness of the composites.

\begin{tabular}{|c|c|c|c|}
\hline Mixture code & Epoxy resin*, kg/m & Boron waste, $\mathrm{kg} / \mathrm{m}^{3}$ & Hardness $\left(H_{\mathrm{p}}\right)$ \\
\hline B0 & 100 & - & 32 \\
\hline B10 & 90 & 10 & 38 \\
\hline B20 & 80 & 20 & 47 \\
\hline B30 & 70 & 30 & 59 \\
\hline B40 & 60 & 40 & 74 \\
\hline B50 & 50 & 50 & 98 \\
\hline
\end{tabular}

\footnotetext{
*Epoxy resin was used with the hardener in the 2:1 ratio.
} 
$21 \times 10^{-5}$ to $3 \times 10^{-5} \mathrm{~mm}^{3} / \mathrm{Nm}$ at $10.0 \mathrm{~N}$, from $27 \times 10^{-5}$ to $3.5 \times 10^{-5}$ $\mathrm{mm}^{3} / \mathrm{Nm}$ at $15.0 \mathrm{~N}$, depending on waste content. In other words, there is approximately 7.7 times enhancement in wear resistance of polymer composites at $15 \mathrm{~N}$ caused by the waste presence, with higher waste concentrations producing larger effects. Thus, the addition of the waste material makes the epoxy material harder and also changes the character of the surface. Wear strength is higher at higher waste concentrations due to more homogeneous distribution of filler particles since they enhance the resistance to abrasion. At the same time, when load values are considered, the wear rate for all specimens increases with load for all waste material ratios. The wear rate increases with an increase of load from 5 to $15 \mathrm{~N}$ due to increase of abrasion and friction on surface of polymer composite.

A relationship between the wear rate and hardness has been investigated and is shown in Figure 3. For each load, the wear resistance increases with an increase of the hardness. The respective equations are provided in inserts to Figure 3. The coefficient of determination $\mathrm{R}^{2}$ is very close to 1.0 for each loading condition, the highest for $15.0 \mathrm{~N}$ $\left(\mathrm{R}^{2}=\right.$ corresponds to the perfect fit).

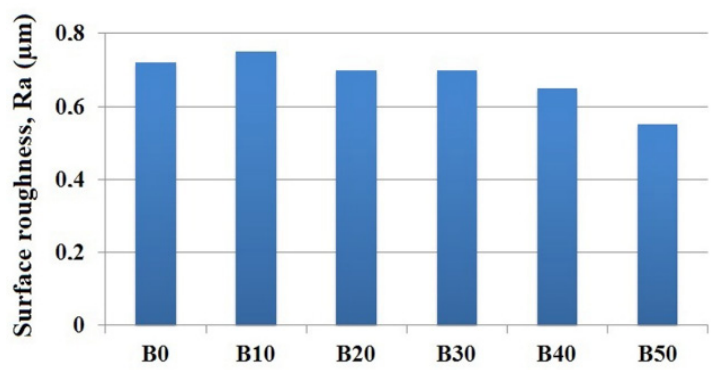

Figure 1. Surface roughness values of epoxy composites with boron waste.

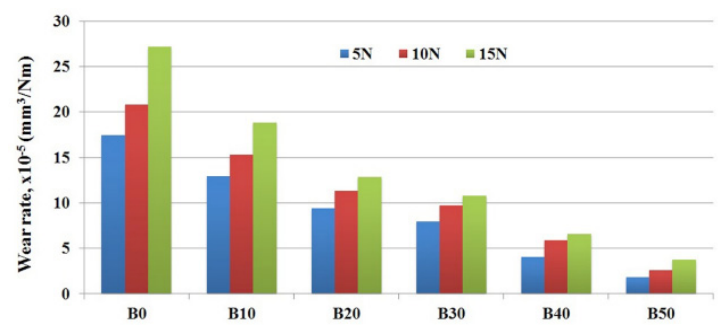

Figure 2. Wear rates of epoxies for various boron waste concentrations.

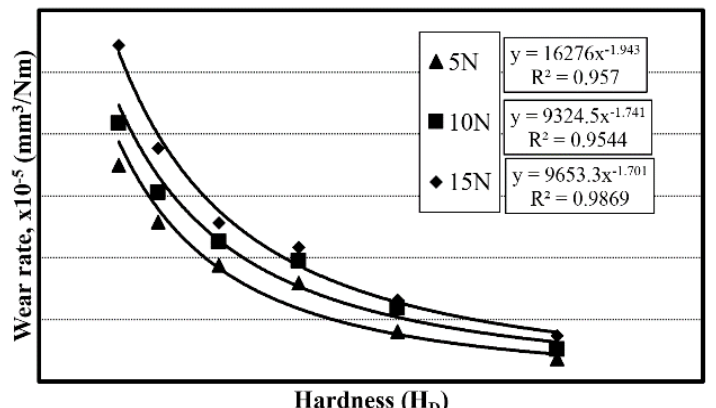

Figure 3. Relationship between hardness and wear rate of the composites in the inserts.

\subsection{Friction}

Steady state dynamic friction values at different loads are reported in Table 3. The highest dynamic friction is seen in the control samples, namely 0.4 . In the composite with $50 \%$ waste the friction is equal to 0.21 , a reduction to almost one half. As expected, increasing the load increases dynamic friction.

An explanation of friction results can be provided in terms of "bumps" on predominantly polymer composite surface. The bumps model has been advanced before ${ }^{[23]}$ and later confirmed in several cases ${ }^{[24,25]}$. Without the filler, the nominal contact area is equal to the real contact area. Addition of the filler results in bumps formation; more filler means lower real contact area. Increasing the load makes the bumps slightly less effective in friction lowering.

We have also pursued in Figure 4 the dependence of the dynamic friction values on the surface roughness. There is a clear correlation between these quantities. $\mathrm{R}^{2}$ values are here reasonably good, the best fit is seen for $15 \mathrm{~N}$.

In turn, we present the relation between dynamic friction and wear rate in Figure 5. A clear correlation emerges in Figure 5:

$$
F=0.164+0.0103 W
$$

Here $\mathrm{F}$ is the dynamic friction; $\mathrm{W}$ is the wear rate as before, calculated from Equation 1.

\subsection{Microstructure}

We observed specimens after ball-on-disk tribometry at $15 \mathrm{~N}$ using an optical microscope and SEM; see Figures 6 and 7, respectively. Importantly, waste material particles are uniformly distributed in the epoxy matrix. In Figures $6 \mathrm{a}$ and $7 \mathrm{a}$, the cracks and deformations can be clearly seen on the surface of the control (pure epoxy) specimen. The largest track width

Table 3. Dynamic friction values under different conditions.

\begin{tabular}{cccc}
\hline Mixture code & $\mathbf{5 . 0} \mathbf{~ N}$ & $\mathbf{1 0 . 0} \mathbf{~ N}$ & $\mathbf{1 5 . 0 ~ N}$ \\
\hline B0 & 0.37 & 0.39 & 0.40 \\
B10 & 0.28 & 0.33 & 0.36 \\
B20 & 0.26 & 0.30 & 0.32 \\
B30 & 0.21 & 0.27 & 0.30 \\
B40 & 0.19 & 0.22 & 0.24 \\
B50 & 0.16 & 0.19 & 0.21 \\
\hline
\end{tabular}

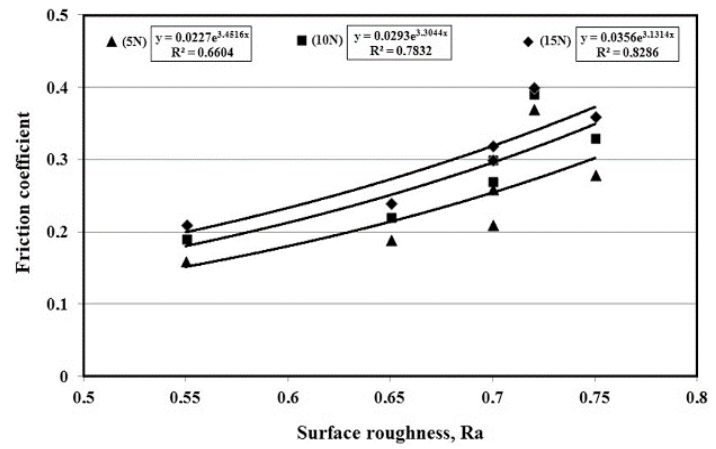

Figure 4. Relationship between dynamic friction and surface roughness. 


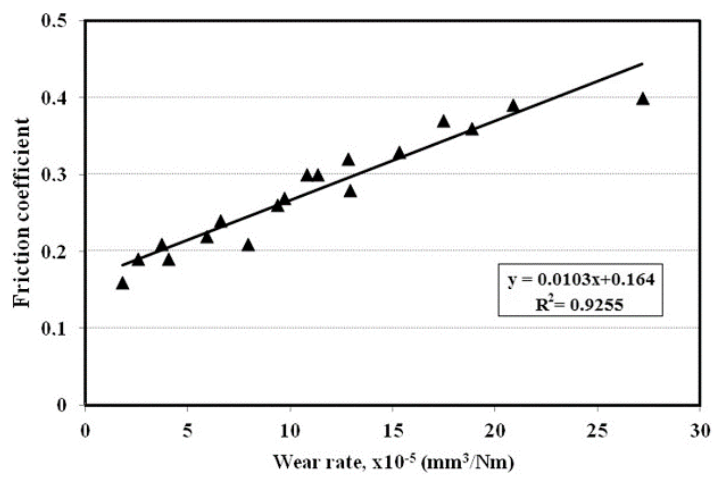

Figure 5. Relationship between dynamic friction and wear rate. is also observed for pure epoxy, possibly due to small air bubbles in the mixtures during the hardening. Needless to say, the microscopy results confirm the findings reported above, particularly in Figure 2.

We have seen in Table 2 that more waste as the filler increases the hardness. The filler also increases the wear resistance, as seen in Figure 3. These facts are reflected in Figures 6 and 7. Figure 6 shows us how the pin moves across 'borders' between the phases; the arrows illustrate such movements.

Pure epoxy without fillers shows traces with tears, breaks and cracks. For the composites we see simpler and relatively homogeneous surfaces.
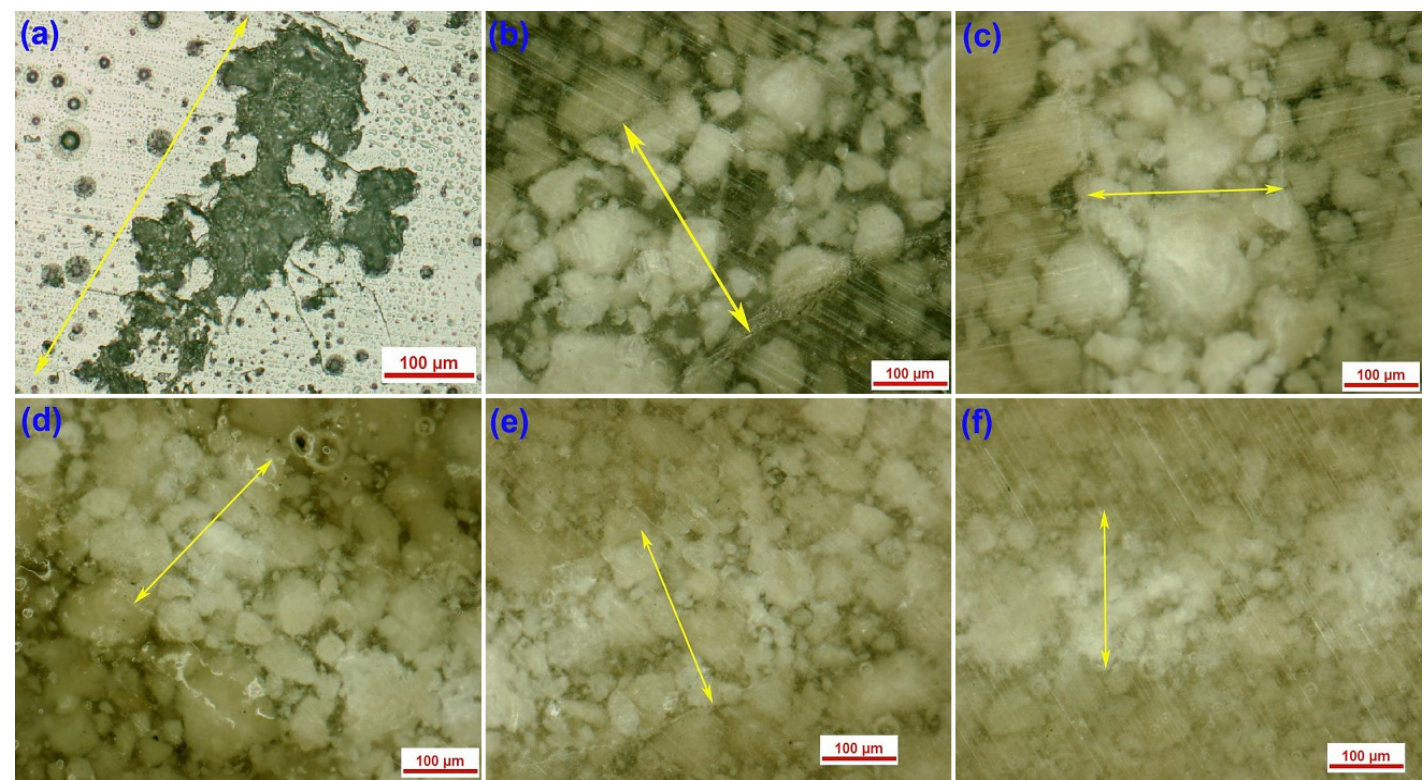

Figure 6. Microstructures of epoxy composites after tribometry for various boron waste concentrations: (a) for pure epoxy, (b) for $10 \%$ waste, (c) for $20 \%$ waste, (d) for $30 \%$ waste, (e) for $40 \%$ and (f) for $50 \%$ waste.
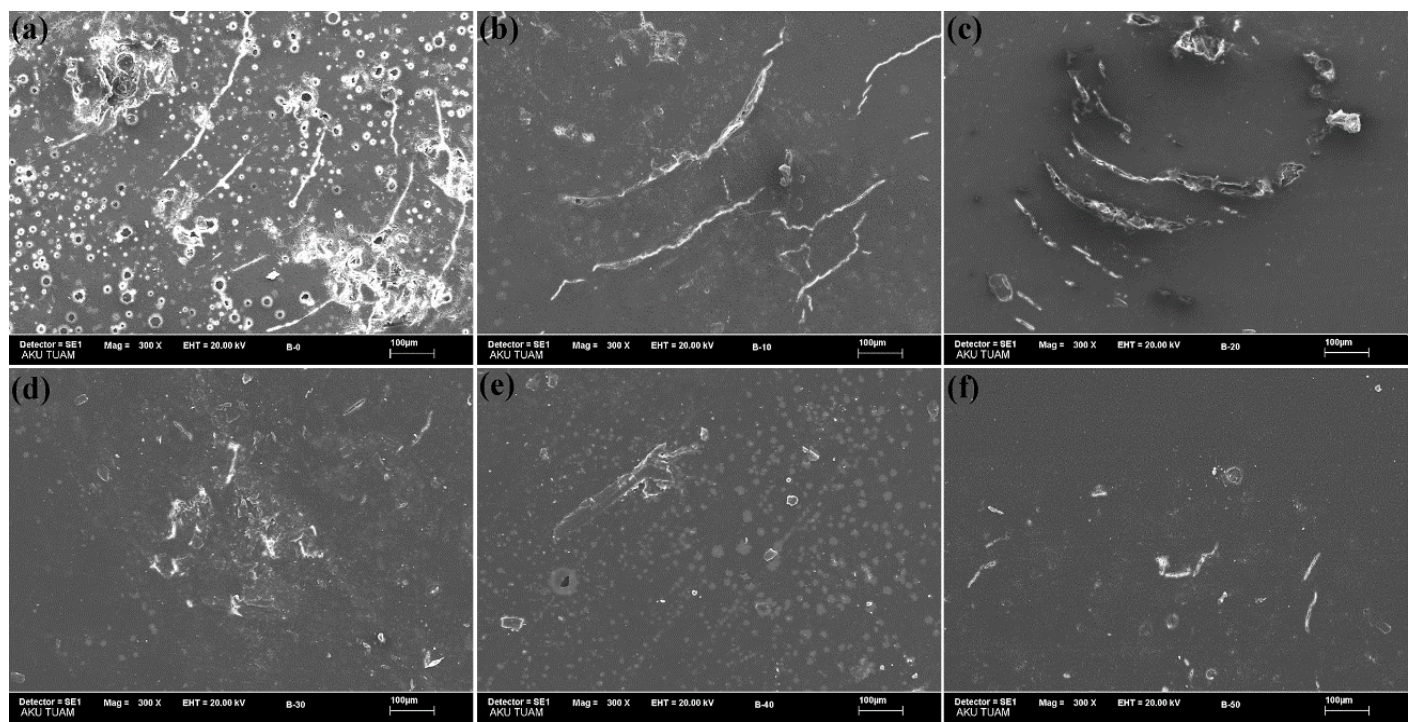

Figure 7. The wear SEMicrographs of epoxy composites after tribometry for various boron waste concentrations: (a) for pure epoxy, (b) for $10 \%$ waste, (c) for $20 \%$ waste, (d) for $30 \%$ waste, (e) for $40 \%$ and (f) for $50 \%$ waste. 


\section{Conclusions}

We report above wear and friction characteristics of epoxy based polymer composites as well as the role of boron-containing waste additives on properties. Several conclusions are derived:

- The hardness values of samples are increased three times by using boron-containing waste material when compared to pure epoxy.

- The surface roughness values are similar to each other in samples with or without waste material content; the lowest roughness is seen for $50 \mathrm{wt}$ \% waste.

- Dynamic friction decreases with increasing waste concentration while it increases slightly with increasing load.

- Wear resistance is higher in high waste material composites, apparently due to more homogeneous distribution of filler particles with high resistance to abrasion. The wear rate for the $50 \mathrm{wt}$. \% boron waste composite is 7.7 times smaller than for the pure epoxy.

- A good was relationship between hardness versus wear rate; coefficient of friction versus roughness; and coefficient of friction versus wear rate is obtained, respectively, for epoxy based and waste material blended polymer composites.

- Microstructure observations show that the waste material particles are uniformly distributed in the epoxy matrix. While the deformations such as tears, breaks and cracks are observed in pure epoxy specimens, there is only trace on the waste material containing samples after the tribometry tests.

\section{Acknowledgements}

The author would like to thank National Boron Research Institute (BOREN) of Turkey, Ankara, for the financial support under the Project No. 2013.Ç0405.

\section{References}

1. Kavas, T., Christogerou, A., Pontikes, Y., \& Angelopoulos, G. N. (2011). Valorisation of different types of boron-containing wastes for the production of lightweight aggregates. Journal of Hazardous Materials, 185(2-3), 1381-1389. http://dx.doi. org/10.1016/j.jhazmat.2010.10.059. PMid:21075514.

2. Kurama, S., Kara, A., \& Kurama, H. (2006). The effect of boron waste in phase and microstructural development of a terracotta body during firing. Journal of the European Ceramic Society, 26(4-5), 755-760. http://dx.doi.org/10.1016/j. jeurceramsoc.2005.07.039.

3. Özdemir, M., \& Öztürk, N. U. (2003). Utilization of clay wastes containing boron as cement additives. Cement and Concrete Research, 33(10), 1659-1661. http://dx.doi.org/10.1016/ S0008-8846(03)00138-8.

4. Brostow, W., Dutta, M., \& Rusek, P. (2010). Modified epoxy coatings on mild steel: tribology and surface energy. European Polymer Journal, 46(11), 2181-2189. http://dx.doi.org/10.1016/j. eurpolymj.2010.08.006.

5. Bilyeu, B., Brostow, W., \& Menard, K. P. (2001). Determination of volume changes during cure via void elimination and shrinkage of an epoxy prepreg using a quartz dilatometry cell. Polimery, 46(11-12), 799-802. Retrieved from http://ichp.pl/ attach.php?id=2849

6. Bilyeu, B., Brostow, W., \& Menard, K. P. (2001). Epoxy thermosets and their applications. III. Kinetic equations and models. Journal of Materials Education, 23(4-6), 189-204. Retrieved from http://www.unt.edu/LAPOM/publications/ pdf\%20articles/Lisa/epoxyJME3.pdf

7. Jang, B. Z. (1994). Advanced polymer composites: principles and applications. Ohio: Metals Park/ASM International.

8. Kim, J., Kang, P. H., \& Nho, Y. C. (2004). Positive temperature coefficient behavior of polymer composites having a high melting temperature. Journal of Applied Polymer Science, 92(1), 394-401. http://dx.doi.org/10.1002/app.20064.

9. Harsha, A. P. (2011). An investigation on low stress abrasive wear characteristics of high performance engineering thermoplastic polymers. Wear, 271(5-6), 942-951. http://dx.doi.org/10.1016/j. wear.2011.03.019

10. Shipway, P. H., \& Ngao, N. K. (2003). Microscale abrasive wear of polymeric materials. Wear, 255(1-6), 742-750. http:/ dx.doi.org/10.1016/S0043-1648(03)00106-6.

11. Cayer-Barrioz, J., Mazuyer, D., Kapsa, Ph., Chateauminois, A., \& Robert, G. (2004). Abrasive wear micromechanisms of oriented polymers. Polymer, 45(8), 2729-2736. http://dx.doi. org/10.1016/j.polymer.2004.02.013.

12. Ginzburg, B. M., Tochil'nikov, D. G., Bakhareva, V. E., Anisimov, A. V., \& Kireenko, O. F. (2006). Polymeric materials for water-lubricated plain bearings. Russian Journal of Applied Chemistry, 79(5), 695-706. http://dx.doi.org/10.1134/ S1070427206050016.

13. Gunes, I., Uygunoglu, T., Ergen, A., Kisıkcılar, T., \& Aksoy, E. (2015). Investigation of wear behavior of borided DIN $20 \mathrm{MoCr} 4$ steel. El-Cezerî Journal of Science and Engineering, 2, 53-58. Retrieved from http://ecjse.com/index.php/ECJSE/ article/view/53

14. Samyn, P., Schoukens, G., Quintelier, J., \& De Baets, P. (2006). Friction, wear and material transfer of sintered polyimides sliding against various steel and diamond-like carbon coated surfaces. Tribology International, 39(6), 575-589. http://dx.doi. org/10.1016/j.triboint.2005.07.029.

15. Cirino, M., Friedrich, K., \& Pipes, R. B. (1988). Evaluation of Polymer Composites for Sliding and Abrasive Wear Applications. Composites, 19(5), 383-392. http://dx.doi.org/10.1016/00104361(88)90126-7.

16. Cirino, M., Pipes, R. B., \& Friedrich, K. (1987). The abrasive wear behaviour of continuous ibre polymer composites. Journal of Materials Science, 22(7), 2481-2492. http://dx.doi org/10.1007/BF01082134.

17. Cirino, M., Friedrich, K., \& Pipes, R. B. (1988). The effect of fiber orientation on the abrasive wear behavior of polymer composite materials. Wear, 121(2), 127-141. http://dx.doi. org/10.1016/0043-1648(88)90038-5.

18. Zhao, G., Hussainova, I., Antonov, M., Wang, Q., \& Wang, T. (2013). Friction and wear of fiber reinforced polyimide composites. Wear, 301(1-2), 122-129. http://dx.doi.org/10.1016/j. wear.2012.12.019.

19. Rao, M., Hooke, C. J., Kukureka, S. N., Liao, P., \& Chen, Y. K. (1998). The effect of PTFE on the friction and wear behaviour of polymers in rolling-sliding contact. Polymer Engineering and Science, 38(12), 1946-1958. http://dx.doi.org/10.1002/ pen.10364.

20. Pihtili, H. (2009). An Experimental Investigation of Wear of Glass Fibre-Epoxy Resin and Glass Fibre-Polyester Resin Composite Materials. European Polymer Journal, 45(1), 149-154. http://dx.doi.org/10.1016/j.eurpolymj.2008.10.006. 
21. Svancarek, P., Lendvayova, S., Galusek, D., Hnatko, M., Vavra, I., \& Wang, X. (2011). Abrasive wear resistance of $\mathrm{SiO} 2$-doped polycrystalline alumina. Wear, 271(5-6), 760-769. http://dx.doi.org/10.1016/j.wear.2011.03.016.

22. Brostow, W., Kovacevic, V., Vrsaljko, D., \& Whitworth, J. (2010). Tribology of polymer and polymer-based composites. Journal of Materials Education, 32(5-6), 273-290.

23. Brostow, W., Kumar, P., Vrsaljko, D., \& Whitworth, J. (2011). Optimization of tribological and mechanical properties of nanocomposites of polyurethane/poly(vinyl acetate)/CaCO3. Journal of Nanoscience and Nanotechnology, 11(5), 3922-3928. http://dx.doi.org/10.1166/jnn.2011.3849. PMid:21780387.

24. Olea-Mejía, O., Brostow, W., Escobar-Alarcón, L., \& ViguerasSantiago, E. (2012). Tribological properties of polymer nanohybrids containing gold nanoparticles obtained by laser ablation. Journal of Nanoscience and Nanotechnology, 12(3), 2750-2755. http://dx.doi.org/10.1166/jnn.2012.5737. PMid:22755118.

25. Brostow, W., Datashvili, T., \& Geodakyan, J. (2012). Tribological properties of ethylene-propylene-diene rubber + polypropylene + thermal-shock-resistant ceramic composites. Polymer International, 61(9), 1362-1370. http://dx.doi.org/10.1002/ pi.4282.

Received: May 23, 2014 Revised: Sept. 09, 2014 Accepted: Nov. 18, 2014 